\title{
Nutritional and nutraceutical properties of different plant parts of fenugreek (Trigonella foenum-graecum L.)
}

\author{
VCM Anu Udaya, I Geethalakshmi, K Rajamani \& D Uma
}

Journal of Agriculture and Ecology

Volume-8 (December, 2019) ISSN: $2456-9410$

\section{Journal of Agriculture}

and Ecology

ISSN: 2456-9410

Volume: 8

Journal of Agriculture and Ecology (2019) 8: 30-37 http://doi.org/10.53911/JAE.2019.8204 


\title{
Nutritional and nutraceutical properties of different plant parts of fenugreek (Trigonella foenum-graecum L.)
}

\author{
VCM Anu Udaya $\varnothing$, I Geethalakshmi, K Rajamani and D Uma ${ }^{1}$ \\ Department of Medicinal and Aromatic Crops, HC\& RI, TNAU, Coimbatore, Tamil Nadu, \\ ${ }^{1}$ Department of Biochemistry, TNAU, Coimbatore, Tamil Nadu \\ Corresponding author: VCM Anu Udaya, Email: anuudayahort@gmail.com
}

\section{Article Info}

Article history

Received: 20 September 2018

Accepted: 10 November 2018

Available online: 5 August 2019

Key Words: Fenugreek leaves and seeds, growth stages, quality, mineral contents.

\begin{abstract}
Studies on influence of different growth stages on physiological and biochemical parameters of fenugreek (Trigonella foenum-graecum L.) was carried out at HC \& RI, TNAU, Coimbatoreduring 2017-18. Seven different plant parts viz., young seedlings (7-10 days after germination), fresh leaf at matured stage (30-40 days after sowing), dry leaf at matured stage (30-40 days after sowing), fresh leaf at matured stage (60-70 days after sowing), dry leaf at matured stage (60-70 days after sowing), dry seed and sprouted seed were tried. The study revealed that, the sprouted seeds and the dried seeds were found to be best with higher quality parameters viz., total protein, total carbohydrate, total phenol, total fat, crude fibre, calcium, magnesium and iron contents. On the other hand, the fresh leaves at matured stage (60-70

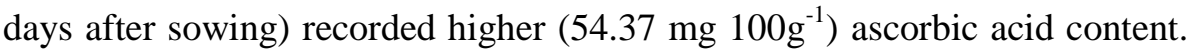
The chlorophyll ' $a$ ', chlorophyll ' $b$ ' and total chlorophyll content in fresh fenugreek leaves ranged from 2.07 to $2.19 \mathrm{mg} \mathrm{g}^{-1}, 1.02$ to $1.16 \mathrm{mg} \mathrm{g}^{-1}$ and 3.09 to $3.35 \mathrm{mg} \mathrm{g}^{1}$ respectively, while dried leaves had lower total chlorophyll content ranged from 0.983 to $1.18 \mathrm{mg} \mathrm{g-}^{1}$.
\end{abstract}

Copyright (C2019 VCM Anu Udaya et al., This is an open access article published under the terms of the Creative Commons Attribution License, which permits unrestricted use, distribution, and reproduction in any medium, provided the original work is properly cited.

Preferred citation: Anu Udaya VCM, Geethalakshmi I, Rajamani K and Uma D. 2019. Nutritional and nutraceutical properties of different plant parts of fenugreek (Trigonella foenum-graecum L.). Journal of Agriculture and Ecology, 8: 30-37; http://doi.org/10.53911/JAE.2019.8204.

\section{Introduction}

Fenugreek (Trigonella foenumgraecum L.) is an important seed spices, originated from South-Eastern Europe and belongs to Fabaceae family. it is an annual herb, commonly known as methi, diploid in nature with chromosome number $2 \mathrm{n}=16$. Fenugreek is a self pollinated crop. The plant is characterized with trifoliate leaves, white papilionaceous flowers, roots with conspicuous root nodules and hard textured golden yellow seeds. The name fenugreek is derived from the Latin word 'Greek hey' illustrating its classical use as fodder. India is the largest producer of fenugreek, and in spices, third largest spice after coriander and cumin. During the year of 2016-17, in India, fenugreek is cultivated in an area of 2, 10,000 ha with an annual production of 2, 97,000 MT. In Rajasthan state alone, it is 
cultivated is an area of $1,57,000$ ha with a production of 1,90,360 tons (Spices Board, 2017). Fenugreek is mainly grown as leafy vegetable throughout India and there is an ample scope for its cultivation as seed spice. It is a short duration crop is fitting well in several cropping system. Seed crop requires cool dry climate and takes about three months duration thus fitting well as a rabi crop after the harvest of kharif main crops like paddy, chillies, cotton and pigeon pea. Fenugreek contains a number of chemical constituents including steroidal sapogenins, 23-26\% protein, $6-7 \%$ fat and $58 \%$ carbohydrates of which about $25 \%$ is dietary fiber. Diosgenin component has been found in the oily embryo of fenugreek. Fenugreek is also a rich source of iron, containing $33 \mathrm{mg} / 100 \mathrm{~g}$ dry weight.

Fenugreek leaves contains seven saponins, graecunins compounds of diosgenin, $86.1 \%$ moisture, $4.4 \%$ protein, $0.9 \%$ fat, $1.5 \%$ minerals, $1.1 \%$ fiber, $6 \%$ carbohydrates, ascorbic acid (220.97 mg per $100 \mathrm{~g}$ of leaves), $\beta$-carotene (19 mg per $100 \mathrm{~g}$ of leaves), vitamin $\mathrm{C}(52 \mathrm{mg})$, thiamine $(40 \mu \mathrm{g})$, riboflavin $(310 \mu \mathrm{g})$ and nicotinic acid $(800$ $\mu \mathrm{g})$. For better retention of nutrients in fenugreek leaves, should be stored in refrigeration, dried in oven, blanched for a short period of time (5mins) and cooked in pressure cooker. Seeds are rich source of vitamin $\mathrm{C}, \beta$-carotene, thiamine, riboflavin, nicotinic acid, folic acid, diosgenin, alkaloids (trigonelline, gentianine, carpaine), rhaponticin (polyphenol compound) and proteins. Germinated seeds have several beneficial properties over ungerminated seeds. Germination improves in vitro protein digestion, as well as fat absorption capacity, higher phenolic and flavonoid content, reduces blood sugar levels and cholesterol in diabetic patients. Considering all these aspects, the main aim of this study is to estimate the nutritional and nutraceutical properties of different growth stages of fenugreek.

\section{Materials and Methods}

The present investigation was carried out during the Rabi season (Nov- Dec). The seeds of CO-2 variety of fenugreek was raised in the polybags for nutritional and nutraceutical analysis. The study was followed by Completely Randomized Block Design (CRD) with three replications. The experiment was conducted with seven different treatments viz., young seedlings (7-10 days after germination), fresh leaf at matured stage (30-40 days after sowing), dry leaf at matured stage (30-40 days after sowing), fresh leaf at matured stage (6070 days after sowing), dry leaf at matured stage (60-70 days after sowing), dry seed and sprouted seed. Physiological and biochemical parameters viz., total chlorophyll content, total protein content, total carbohydrate content, total phenol content, total fat, crude fibre content, total polyphenol content, ascorbic acid content, calcium, magnesium and iron contents were analyzed and the following methods were used:

\section{Total chlorophyll content ( $\left.\mathrm{mg} \mathrm{g}^{-1}\right)$}

The fully matured leaves of fenugreek were collected, weighed and macerated in a homogenizer with $80 \%$ acetone. The extract was centrifuged at $4000 \mathrm{rpm}$ for 15 minutes. The supernatant was collected and made up to a known volume. The absorbance of extract was read in a spectronic 20 photoelectric- colorimeter at 645 and $663 \mathrm{~nm}$ and expressed in $\mathrm{mg} \mathrm{g}^{-1}$ leaf tissue (Reuter et al. 1986).

\section{Total soluble protein content $\left(\mathrm{mg} \mathrm{g}^{-1}\right)$}

The Lowry's method of estimating soluble protein as described by (Lowry et al. 1951) was employed in the study.

Total carbohydrate content ( $\mathrm{mg} \mathrm{g}^{-1}$ ) 
The total carbohydrate content in fenugreek was carried out by Anthrone method (Firestone 1990).

\section{Total phenol content $\left(\mathrm{mg} \mathrm{g}^{-1}\right)$}

Total phenol content of the leaves was estimated by using the procedure proposed by Malik and Singh (1980). Leaf sample (500 $\mathrm{mg}$ ) was taken and cut into small leaf bits in five $\mathrm{ml}$ of $80 \%$ ethanol and kept in the hot water bath for 10 minute and the content was cooled. The leaf sample was macerated along with another $5 \mathrm{ml}$ of $80 \%$ ethanol and centrifuged at $5000 \mathrm{rpm}$ for 10 minutes. The supernatant was collected and the volume made up to $25 \mathrm{ml}$ with distilled water. To the $1 \mathrm{ml}$ of the supernatant, $2 \mathrm{ml}$ of $20 \%$ sodium carbonate and $1 \mathrm{ml}$ of folin's reagent were added. After 10 minutes, the OD was measured at $650 \mathrm{~nm}$..

\section{Fat content (\%)}

Fat content of fenugreek was determined by Soxhlet Method (AOAC, 1995). 2-3 $\mathrm{g}$ of dried sample was weighed in a thimble and places it in the Soxhlet apparatus. The required volume of solvent (petroleum ether, boiling point of $40-60^{\circ} \mathrm{C}$ or ethyl ether or hexane) was added and connected to condenser and extract for 16 hours. The thimble was removed and the excess of ether was evaporated from the solvent flask on a hot water bath and dry the flask at $105^{\circ} \mathrm{C}$ for 30 min. The flask was cooled in desiccators and weighed $(\mathrm{g})$.

Final weight of beaker - empty weight of beaker

Fat content $(\%)=$ $\times 100$

\section{Crude fibre content (\%)}

The crude fibre was calculated according to the method of Joslyn (1970) and expressed in percentage $(\%)$.

\section{Polyphenol oxidase activity $\left(\mathrm{min}^{-\mathbf{1}}\right)$}

Polyphenol oxidase was assayed using the method suggested by Srivastava (1987). Standard reaction mixture contains $1.5 \mathrm{ml}$ of $0.1 \mathrm{M}$ phosphate buffer ( $\mathrm{pH} 6.5$ ), $0.5 \mathrm{ml}$ of enzyme preparation and $0.5 \mathrm{ml}$ of $0.01 \mathrm{M}$ catechol. At the start of the enzyme reaction, the absorbance was set to zero at $494 \mathrm{~nm}$. The changes in the absorbance were recorded at 30 seconds interval and the polyphenol oxidase activity was expressed as changes in the OD of the reaction mixture per min $\mathrm{g}^{-1}$ of fresh weight of tissue.

\section{Ascorbic acid content (mg $\left.100 \mathrm{~g}^{-1}\right)$}

Ascorbic acid content was determined by Horwitz (1975) method.
Weight of sample

\section{Calcium content (mg $\left.100 \mathrm{~g}^{-1}\right)$}

Calcium was determined by precipitating it as calcium oxalate and titrating the solution of oxalate in dilute $\mathrm{H}_{2} \mathrm{SO}_{4}$ against standard $\mathrm{KMnO}_{4}$ employing Firestone (1990).

\section{Magnesium and Iron content $\left(\mathrm{mg}^{100 \mathrm{~g}^{-1}}\right)$}

To estimate $\mathrm{Fe} \& \mathrm{Mg}$, digest the mixture with di-acid (nitric acid \& perchloric acid in 2: 1ratio) mixture and dilute it to 50 $\mathrm{ml}$ with deionized water and directly run on atomic absorption spectrophotometer. The standard was calibrated on AAS and then samples are read. The concentration reading given by AAS was multiplied by the dilution factor used during digestion.

\section{Statistical analysis}

The mean values of all the laboratory experiments were subjected to statistical analysis. The results of the experiments were statistically analyzed using SPSS (Statistical 
Package for the Social Sciences) software developed by Nei 1978 .

\section{Results and Discussion}

\section{Physiological and biochemical parameters}

The quality parameters were significantly influenced by all the different treatments of fenugreek. Data on chlorophyll 'a', chlorophyll 'b' and total chlorophyll content, total soluble protein, total carbohydrate, total fat, total crude fibre content, total polyphenol content, ascorbic acid content, calcium, magnesium and iron contents were analyzed and presented in the tables. The chlorophyll 'a' content was higher $\left(2.19 \mathrm{mg} \mathrm{g}^{-1}\right)$ in young seedlings $\left(\mathrm{T}_{1}\right)$ followed by $\mathrm{T}_{2}$ (fresh leaf at 30-40 DAS) with $2.13 \mathrm{mg}$ $\mathrm{g}^{-1}$. While in $\mathrm{T}_{5}$ (dry leaf at 60-70 DAS) recorded lower chlorophyll ' $a$ ' content of $0.643 \mathrm{mg} \mathrm{g}^{-1}$ (Table 1). The chlorophyll ' $b$ ' content was higher in young seedling $\left(\mathrm{T}_{1}\right)$ with $1.16 \mathrm{mg} \mathrm{g}^{-1}$. While lowest content was recorded in $\left(T_{5}\right)$ dry leaf at 60-70 DAS with
$0.216 \mathrm{mg} \mathrm{g}^{-1}$. Total chlorophyll content was higher in treatment $\left(\mathrm{T}_{1}\right)$ young seedling exhibited with $3.35 \mathrm{mg} \mathrm{g}^{-1}$, followed by the treatment $\left(\mathrm{T}_{2}\right)$ fresh leaf at 30-40 days after sowing (3.22 $\left.\mathrm{mg} \mathrm{g}^{-1}\right)$ while lower total chlorophyll content was registered in treatment $\left(\mathrm{T}_{5}\right)$ dry leaf at 60-70 days after sowing with $0.983 \mathrm{mg} \mathrm{g}^{-1}$, respectively. Chlorophyll is a pigment which is responsible for antioxidant activity. It gets diminished with maturity due to biosynthesis ends up to the stages of growth after which it declines. It was reported that total chlorophyll, chlorophyll 'a', 'b' have been decreased due to enhancement of chlorophyllase enzyme activity which might have resulted in degradation of chloroplast, when the chloroplast degradation occurs (Ramakrishnan et al. 1969). It was also reported that reduction in total chlorophyll content was due to chlorophyll destruction at senescence while cutting was done at second and third time in comparison to first (Drew \& Sisworo 1977).

Table 1. Effect of different growth stages of fenugreek on chlorophyll ' $a$ ', chlorophyll ' $b$ ' and total chlorophyll content

\begin{tabular}{lccc}
\hline \multicolumn{1}{c}{ Treatment } & $\begin{array}{c}\text { Chlorophyll 'a' } \\
\text { content } \\
\left(\mathrm{mg} \mathrm{g}^{-1}\right)\end{array}$ & $\begin{array}{c}\text { Chlorophyll 'b' } \\
\text { content } \\
\left(\mathrm{mg} \mathrm{g}^{-1}\right)\end{array}$ & $\begin{array}{c}\text { Total } \\
\text { chlorophyll } \\
\text { content } \\
\left(\mathrm{mg} \mathrm{g}^{-1}\right)\end{array}$ \\
\hline $\begin{array}{l}\mathrm{T}_{1} \text { (Young seedlings at 7-10 days } \\
\text { after germination) }\end{array}$ & 2.19 & 1.16 & 3.35 \\
$\mathrm{~T}_{2}$ (Fresh leaf at matured stage at 30- & 2.13 & 1.09 & 3.22 \\
40 days after sowing) & & & \\
$\mathrm{T}_{3}$ (Dry leaf at matured stage at 30- & 0.964 & 0.341 & 1.18 \\
40 days after sowing) & & & 3.09 \\
$\mathrm{~T}_{4}$ (Fresh leaf at matured stage at 60- & 2.07 & 1.02 & 0.983 \\
70 days after sowing) & 0.643 & 0.216 & 2.36 \\
$\mathrm{~T}_{5}$ (Dry leaf at matured stage at 60- & 1.60 & 0.765 & 0.052 \\
70 days after sowing) & 0.037 & 0.014 & 0.164 \\
\hline Mean & 0.116 & 0.045 & 0.115 \\
SEd & 0.081 & 0.032 & \\
CD (1\%) & &
\end{tabular}


The chlorophyll content increased during development up to 28 days after this duration, the chlorophyll content was decreased (Parekh et al. 1990). The chlorophyll " $a$ " is considered as the main photosynthetic pigment in higher plants, in which this pigment is responsible by the light absorption that promotes the start of photosynthesis process (Taiz \& Zeiger 2002). The maintenance of the chlorophyll " $b$ " of the plants was promoted by the increase of the antioxidant enzyme activities as super oxide dismutase and catalase (Gong et al. 2005). The soluble protein content was higher in $\left(\mathrm{T}_{7}\right)$

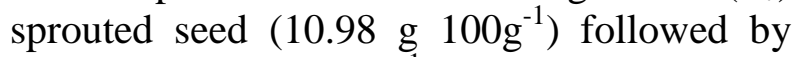


$\left.100 \mathrm{~g}^{-1}\right)$ protein content was recorded in $\left(\mathrm{T}_{5}\right)$ dried leaves at 60-70 DAS (Table 2). Proteins are involved in processes such as catalasing chemical reactions, facilitating membrane transport, intracellular structure and energy generating reactions involving electron transport. Total carbohydrate content was higher in dry seed with $21.24 \mathrm{mg} \mathrm{g}^{-1}$ and followed by the sprouted seed which registered $18.07 \mathrm{mg} \mathrm{g}^{-1}$. The carbohydrate content was found to be higher in fresh leaves (5.09 to $11.88 \mathrm{mg} \mathrm{g}^{-1}$ ) than the dried leaves. The total phenol content was higher in the form of dry seed and followed by sprouted seed with $4.86 \mathrm{mg} \mathrm{g}^{-1}$ and $4.12 \mathrm{mg} \mathrm{g}^{-1}$. The

Table 2. Effect of different growth stages of fenugreek on soluble protein, total carbohydrate and total phenol content

\begin{tabular}{lccc}
\hline \multicolumn{1}{c}{ Treatment } & $\begin{array}{c}\text { Soluble protein } \\
\text { content }\left({\left.\mathrm{g} 100 \mathrm{~g}^{-1}\right)}\right.\end{array}$ & $\begin{array}{c}\text { Total } \\
\text { carbohydrate } \\
\text { content }\left(\mathrm{mg} \mathrm{g}^{-1}\right)\end{array}$ & $\begin{array}{c}\text { Total phenol } \\
\text { content }\left(\mathrm{mg} \mathrm{g}^{-1}\right)\end{array}$ \\
\hline $\begin{array}{l}\mathrm{T}_{1} \text { (Young seedlings at } \\
\text { days after germination) }\end{array}$ & 8.93 & 11.88 & 1.42 \\
$\begin{array}{l}\mathrm{T}_{2} \text { (Fresh leaf at matured stage } \\
\text { at 30-40 days after sowing) }\end{array}$ & 8.75 & 6.51 & 2.64 \\
$\begin{array}{l}\mathrm{T}_{3} \text { (Dry leaf at matured stage at } \\
\begin{array}{l}30-40 \text { days after sowing) } \\
\mathrm{T}_{4} \text { (Fresh leaf at matured stage } \\
\text { at 60-70 days after sowing) }\end{array}\end{array}$ & 6.74 & 5.09 & 1.08 \\
\end{tabular}

phenolic compounds may contribute directly to the antioxidant action; therefore, it is necessary to investigate total phenolic content (Syeda et al. 2008). The total fat content was lower in the form of dried leaves at the stage of 30-40 DAS with $0.90 \%$. In the form of seeds, both dry and sprouted have the higher fat content which recorded $5.57 \%$ and $4.38 \%$ respectively (Table 3). Low fat content in foods enhance storage life due to reduced chance of lipid peroxidation. The result of the favorably with the works of Singh et al. (2010) and Berwal et al. (2018). Total crude fibre content was higher in treatment $\left(\mathrm{T}_{6}\right)$ dry seed $(14.67 \%)$, which was followed by $\left(\mathrm{T}_{7}\right)$ sprouted seed $(12.58 \%)$. The lower value of crude fibre was obtained from young seedlings $\left(\mathrm{T}_{1}\right)$ with $8.43 \%$ respectively. \%). In leaves, the fibre content was slightly increased from young seedlings to matured stage. The increase in crude fibre content was probably due to the reason that with advancement of ages, the concentrations of carbohydrate increases. Because during the time of maturity the starch was translocated, amino acid and proteins were synthesized and after this sugar were produced, therefore, the crude fibre content increased during maturity (Singh \& Pradhan 1973; Haldhar et al. 2018). total fat obtained from this study compares 


\begin{tabular}{lccc}
$\mathrm{T}_{5}$ (Dry leaf at matured stage at & 6.25 & 5.25 & 1.26 \\
$60-70$ days after sowing) & 10.52 & 21.24 & 4.86 \\
$\mathrm{~T}_{6}$ (Dry seed) & 10.98 & 18.07 & 4.12 \\
$\mathrm{~T}_{7}$ (Sprouted seed) & 8.63 & 10.65 & 2.70 \\
\hline Mean & 0.210 & 0.288 & 0.068 \\
$\mathrm{SEd}$ & 0.624 & 0.856 & 0.203 \\
$\mathrm{CD}(1 \%)$ & 0.450 & 0.617 & 0.147 \\
$\mathrm{CD}(5 \%)$ &
\end{tabular}

Table 3. Effect of different growth stages of fenugreek on total fat, total crude fibre and total polyphenol content

\begin{tabular}{lccc}
\hline \multicolumn{1}{c}{ Treatment } & $\begin{array}{c}\text { Total fat content } \\
(\%)\end{array}$ & $\begin{array}{c}\text { Total crude Fiber } \\
\text { content }(\%)\end{array}$ & $\begin{array}{c}\text { Total polyphenol } \\
\text { content }\left(\mathrm{min}^{-1}\right)\end{array}$ \\
\hline $\begin{array}{l}\mathrm{T}_{1} \text { (Young seedlings at } 7-10 \\
\text { days after germination) }\end{array}$ & 1.01 & 8.43 & 0.324 \\
$\mathrm{~T}_{2}$ (Fresh leaf at matured stage & & & 1.013 \\
at 30-40 days after sowing) & 1.16 & 10.62 & 0.937 \\
$\mathrm{~T}_{3}$ (Dry leaf at matured stage at & & & \\
30-40 days after sowing) & 0.903 & 8.57 & 1.245 \\
$\mathrm{~T}_{4}$ (Fresh leaf at matured stage & & & \\
at 60-70 days after sowing) & 1.24 & 11.47 & 0.987 \\
$\mathrm{~T}_{5}$ (Dry leaf at matured stage at & & & 1.357 \\
60-70 days after sowing) & 0.918 & 8.92 & 0.973 \\
$\mathrm{~T}_{6}$ (Dry seed) & 5.57 & 14.67 & 0.977 \\
$\mathrm{~T}_{7}$ (Sprouted seed) & 4.38 & 12.58 & 0.026 \\
\hline $\mathrm{Mean}$ & 2.17 & 10.75 & 0.077 \\
$\mathrm{SEd}$ & 0.045 & 0.146 & 0.055 \\
$\mathrm{CD}(1 \%)$ & 0.133 & 0.435 & 0.313 \\
$\mathrm{CD}$ (5\%) & 0.096 & & \\
\hline
\end{tabular}

The highest polyphenol content was observed in the form of dry seed $\left(1.357 \mathrm{~min}^{-}\right.$ $\left.{ }^{1}\right)$. The highest polyphenol content was found in matured leaves at 60-70 DAS. The polyphenolic compounds of fenugreek seeds can be considered cytoprotective during EtOH induced liver damage. Polyphenolic flavonoids have been shown to protect various cell types from oxidative stress-mediated cell injury. Polyphenols are used for the prevention and cure of various diseases, which are mainly associated with free radicals. The antioxidant activity may result from the neutralization of free radical initiating oxidation processes or from the termination of radical chain reactions (Gupta \& Singh 2002). Ascorbic acid content was found highest in the form of fresh leaves at matured stage at $60-70$ DAS $(54.37 \mathrm{mg}$ $\left.100 \mathrm{~g}^{-1}\right)$ followed by fresh leaves at 30-40 DAS $54.26 \mathrm{mg}^{100 \mathrm{~g}^{-1}}$ (Table 4). The difference in ascorbic acid content was probably due to balance of oxidation and reduction of ascorbic dehydro ascorbic acid that leads to determination of vitamin $\mathrm{C}$ content of leafy vegetables. (Sahoo \& Acharyya, 2005). Fresh leaves at matured stage (60-70 days after sowing) have the higher amount of calcium content with $329.56 \mathrm{mg} 100 \mathrm{~g}^{-1}$. The lowest amount was found in sprouted and dry seed which recorded $197.51 \mathrm{mg} 100 \mathrm{~g}^{-1}$ and 192.51 mg $100 \mathrm{~g}^{-1}$, respectively. Jones \& Lunt, (1967) reported that calcium functions both as a 
structural component and as a cofactor of certain enzymes. Calcium has a significant role in nitrogen metabolism. Highest magnesium content was registered in the form of sprouted seed followed by dry seed with the

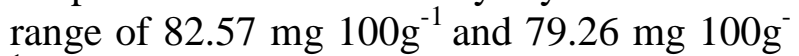

1 . Magnesium is required for ribosome integrity. This might explain the observation that high amounts of magnesium appear to be associated with young growing tissue containing high protein level. Iron content was

Table 4. Effect of different growth stages of fenugreek on ascorbic acid, calcium, magnesium and iron content

\begin{tabular}{|c|c|c|c|c|}
\hline Treatment &  & $\begin{array}{c}\text { Calcium } \\
\text { content } \\
\left(\mathrm{mg} 100 \mathrm{~g}^{-1}\right)\end{array}$ & 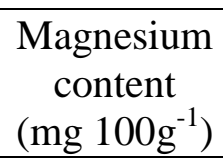 & $\begin{array}{l}\text { Iron content } \\
\left(\mathrm{mg} 100 \mathrm{~g}^{-1}\right)\end{array}$ \\
\hline $\begin{array}{l}\mathrm{T}_{1} \text { (Young seedlings at } 7-10 \\
\text { days after germination) }\end{array}$ & 52.02 & 318.26 & 50.32 & 15.03 \\
\hline $\begin{array}{l}\mathrm{T}_{2} \text { (Fresh leaf at matured stage } \\
\text { at 30-40 days after sowing) }\end{array}$ & 54.26 & 324.63 & 50.97 & 16.09 \\
\hline $\begin{array}{l}\mathrm{T}_{3} \text { (Dry leaf at matured stage } \\
\text { at 30-40 days after sowing) }\end{array}$ & 51.17 & 315.72 & 49.23 & 15.21 \\
\hline $\begin{array}{l}\mathrm{T}_{4} \text { (Fresh leaf at matured stage } \\
\text { at } 60-70 \text { days after sowing) }\end{array}$ & 54.37 & 329.56 & 52.29 & 16.25 \\
\hline $\begin{array}{l}T_{5} \text { (Dry leaf at matured stage } \\
\text { at } 60-70 \text { days after sowing) }\end{array}$ & 52.32 & 317.38 & 50.19 & 15.43 \\
\hline $\mathrm{T}_{6}($ Dry seed $)$ & 42.96 & 192.51 & 79.26 & 14.49 \\
\hline $\mathrm{T}_{7}($ Sprouted seed $)$ & 40.07 & 197.48 & 82.57 & 17.27 \\
\hline Mean & 49.61 & 285.07 & 59.26 & 15.68 \\
\hline SEd & 1.262 & 6.168 & 1.529 & 0.357 \\
\hline $\mathrm{CD}(1 \%)$ & 3.756 & 18.36 & 4.55 & 1.06 \\
\hline $\mathrm{CD}(5 \%)$ & 2.706 & 13.23 & 3.279 & 0.765 \\
\hline
\end{tabular}

\section{Conclusion}

Over all it can be concluded that the dried and sprouted seed recorded higher amount of soluble protein, carbohydrate, total fat, crude fibre, total polyphenol, magnesium and iron contents. Fresh leaves at 60-70 days after sowing contain higher amount of ascorbic acid and calcium content. higher in the form of sprouted seed $(17.27 \mathrm{mg}$ $100 \mathrm{~g}^{-1}$ ) followed by fresh leaves at 60-70 days


Iron is implicated in the synthesis of chlorophyll in plants and essential for the conversion of coproporphyrinoges to protoporphyrinogent and its activity was highest in young leaves. Punia, (2006) also reported that leafy vegetables are the good source of calcium and iron content.

\section{References}

Bashri G, Singh VP \& Prasad SM. 2013. A review on nutritional and antioxidant values, and medicinal properties of Trigonella foenum-graecum L. Biochemistry and Pharmacology, 2 (118).

Berwal MK, Goyal P \& Chugh LK. 2018. Exploitation of pearl millet germplasm for identification of low grain phytate containing parental line. Journal of Agriculture and Ecology, 6: 39-46. 
Drew M, \& Sisworo E. 1977. Early effects of flooding on nitrogen deficiency and leaf chlorosis in barley. New Phytologist, 79(3): 567-571.

Firestone D. 1990. Official methods of analysis of the Association of Official Analytical Chemists. Arlington, USA.

Gong H, Zhu X, Chen K, Wang S \& Zhang C. 2005. Silicon alleviates oxidative damage of wheat plants in pots under drought. Plant Science, 169(2): 313-321.

Gupta K \& Singh J. 2002. Anti-nutritional and flatulence factors at various stages of vegetative growth of fenugreek (Trigonella foenum-graecum L.) leaves. Journal of food science and technology, 39(5): 525-527.

Haldhar SM, Berwal MK, Samadia DK, Kumar R, Gora JS \& Choudhary S. 2018. Biochemical basis of plant-insect interaction in arid horticulture crops: a scientific review. Journal of Agriculture and Ecology, 6: 1-16.

Horwitz W. 1975. Association of official analytical chemists (AOAC) methods. George Banta Company, Menasha, WI.

Jones RW \& Lunt O. 1967. The function of calcium in plants. The Botanical Review, 33(4): 407-426.

Joslyn MA. 1970. Methods in food analysis: physical, chemical, and instrumental methods of analysis (Vol. 9): Academic Press.

Lowry OH, Rosebrough NJ, Farr AL \& Randall RJ. 1951. Protein measurement with the Folin phenol reagent. Journal of biological chemistry, 193(1): 265-275.

Malik CP \& Singh M. 1980. Plant enzymology and histo-enzymology.

Nei M. 1978. Estimation of average heterozygosity and genetic distance from a small number of individuals. Genetics, 89(3): 583-590.

Parekh D, Puranik RM \& Srivastava H. 1990. Inhibition of chlorophyll biosynthesis by cadmium in greening maize leaf segments.
Biochemie und Physiologie der Pflanzen, 186(4): 239-242.

Punia D. 2006. Development And Nutritional Evaluation Of Traditional Food Products Incorporating Calcium Rich Underutilized Grains And Leaves. Chaudhary Charan Singh Haryana Agricultural University; Hisar.

Ramakrishnan K, Nambiar K \& Alagianagalingam M. 1969. Physiology of virus-infected plants. Paper presented at the Proceedings of the Indian Academy of Sciences-Section B.

Reuter D, Robinson J, Peverill K, Price G \& Lambert M. 1986. Guidelines for collecting, handling, and analyzing plant materials. Plant Analysis: An Interpretation Manual. Inkata Press, Melbourne, Australia, 11-35.

Sahoo B \& Acharyya P. 2005. Comparative studies on nutritional status of leafy vegetables. Crop Research-Hisar, 30(3): 406.

Singh P, Singh U, Shukla M \& Singh R. 2010. Variation of some phytochemicals in methi and saunf plants at different stages of development. Journal of Herbal Medicinal and Toxicology, 4(2), 93-99.

Singh R \& Pradhan K. 1973. Studies on the chemical composition of forages by using methods of partitioning higher carbohydrates. 180.

Spices Board I. 2017. Cochin, Kerala, India.

Srivastava S. 1987. Peroxidase and Poly-Phenol Oxidase in Brassica juncea Plants Infected with Macrophomina phaseolina (Tassai) Goid. and their Implication in Disease Resistance. Journal of Phytopathology, 120(3): 249-254.

Syeda BB, Muhammad I \& Shahabuddin M. 2008. Antioxidant activity from the extract of fenugreek seeds. Pakistan Journal of Analytical and Environmental Chemistry, 9(2): 78-83.

Taiz L \& Zeiger E. 2002. Plant Physiology. 3rd. Ed. Pub. Sinauer. 